\title{
The Impact of Service Quality on Students' Satisfaction in Higher Education Institutes of Punjab
}

\author{
Muhammed Ehsan Malik \\ University of the Punjab, Pakistan \\ E-mail: drmalikehsan@hotmail.com \\ Rizwan Qaiser Danish \\ University of the Punjab, Pakistan \\ E-mail: rdanish2000@yahoo.co.uk
}

Ali Usman

University of the Punjab, Pakistan

Tel: 92-0334-447-7533_E-mail: usamaz_07@hotmail.com

\begin{abstract}
In today's competitive environment, the education has not only become a major industry and need of the day but it is also an investment by the parents for their children. In public as well as in private sector the quality of education is an important factor that is considered for attracting and retaining the students who want to get higher education. The objective of this research is to analyze the impact of different quality services on student satisfaction in higher educational institutes of a big division of Punjab province of Pakistan. Both public and private sector institutes are included in this study. Data was collected from 240 students of business courses either enrolled in master program or graduation program in provincially chartered universities of the Gujranwala region. Sample comprised of both male and female students in equal ratio. The results show that students are overall satisfied with services of Tangibility, Assurance, Reliability and Empathy but not much satisfied with parking facilities, computer labs, cafeteria services, complaint handling system. Recommendations and implications for policy makers are discussed and guidelines for future research are also provided.
\end{abstract}

Keywords: Service Quality, Education, Students’ Satisfaction, Perceived Quality 


\section{Introduction}

Education is such a prestigious and fruitful investment that it always rewards in multiple ways. The strong and effective educational system results in the greater performance of the students. The educational institutions where the system is affective and administration is willing to provide the quality services always enjoy more incoming of brilliant and talented students. In order to make the institution progressive and effective the knowledge of students' expectations, academic preferences and quality perception about the educational environment should be kept by the higher authorities of the institute (Palacio, Meneses and Perez 2002). Particularly the students who are at a higher academic level i.e. studying in a higher educational institution seek more quality education and perfection of the system at study place because it satisfies their esteem and develops them with all the essentials and capabilities to be an effective educational personality. According to (Rowley, 1996) the students of those institution are more capable, good performers and productive who retain the better educational service quality and provide their students what they want for their strong academic and carrier accomplishment. The students seek empathy, responsiveness, assurance during their academic development process which then facilitates them to gain extra potential to compete in the market. It is therefore, the effectiveness of the administration and management of a higher educational institution that it facilitates the students with quality assurance and personality grooming so that the students can take maximum out of it (LeBlanc and Nguyen 1997).

\section{Literature Review}

\subsection{Student Satisfaction}

Kotler and Clarke (1987) define satisfaction as the desirous outcome of a task or job that pleases one's esteem. Rad \& Yarmohammadian (2006) defined it as the willful accomplishment which results in one's contentment. The satisfaction plays a major role in the determining the originality and accuracy of a system especially the educational system as higher the level of satisfaction the higher will be the level of students' grooming their skill development, course knowledge and mentality. According to Zeithaml (1988) satisfaction is the resultant outcome of an institution's administrative as well as educational system's coherent performance. Because the students will be more satisfied and motivated for completing their studies if the institution provides an environment which facilitates learning i.e. the institution contains proper infrastructure for educational utility accumulated with essential parameters of professional and academic development. (Rodie and Kleine 2000) posited a view that the students will be more motivated, loyal and good performers if their institution holds essential educational facilities with affective staff of teaching and training. The teachers' performance in the class and outside the class is a significant feature of enhancing students' impartiality, motivation and satisfaction. According to Wachtel, (1998) the students' rate their course instructors' performance and his methodology of teaching as the prime indicators in their educational development and successful completion of their studies because higher the intellectual ability of the instructor the better will be the students' evaluation (Edstrom, 2008) and consequently more will be the reliability on the teaching staff (Sproule, 2000). Teachers' ability, excellence, coordination and reasonability greatly influence students' class 
performance. The students are greatly influenced by the educational activities their teacher or instructor coordinates for them. Shevlin, Banyard, Davies and Griffith (2000) stated that the teachers who teach with punctuality, accuracy, reasonability and logical approach in a student friendly manner are more popular. (Elliot and Shin 2002). Because students level of satisfaction increases by working with those course instructors and lecturers who properly handle the assignments, projects, exams and facilitate students' logical reasoning and aptitude development (Dalton\& Denson 2009).

\subsection{Perceived Service Quality}

The perceived quality is defined as the ones' justification about the excellence of a product or service ( Zammuto et al. 1996). According to Dyson et al., 1996 the service quality is so called the better and standardized output delivered by a service. The service quality in the educational sector particularly in the higher educational institutions is the fundamental aspect of educational excellence. According to (Alridge and Rowley, 2001) when students perceive the institution's quality and standardized learning environment facilitated with intellectual faculty, appropriate facilities of learning and infrastructure, their interest in their organization will explicitly be retained. The students are motivated from the academic as well as the administrative efficiency of their institution. Spooreen, et. al (2007) posited a view that the organizational harmony, teachers' intellectual ability, professional development, transparency in students' evaluation, feedback and training are the important features that mentally develop the students . The maintenance of other essentials of quality service in education i.e. well managed and updated libraries, security systems, medical facilities, class decoration and facilitation with multimedia and sitting arrangements along with administrative staff's cooperation play a vital role in educational support and developement (Dick and Basu 1994). According to Soutar and McNeil (1996) both academic and administrative issues of an institution are extremely important in determining the performance of students, development of organizational image and quality assurance. Elliot and Shin (2002) found that the highly significant variables in the model that appear to directly impact on overall customer satisfaction with university performance

(1) Excellence of instruction in major

(2) Able to get desired classes

(3) Knowledgeable advisor

(4) Knowledgeable faculty

(5) Overall quality of instruction

(6) Tuition paid is a worthwhile investment

(7) Approachable advisor

(8) Safe and secure campus

(9) Clear and reasonable requirements for major 
(10) Availability of advisor

(11) Adequate computer labs,

(12) Fair and unbiased faculty (and

(13) Access to information

Where the students also get motivated from the reliability of the facilities they are provided with, as higher the quality they perceive the higher will be their attraction and affiliation (Keller, 1993).

The availability of other academic facilities like intellectual faculty, advisors, carrier counseling depertement are the features that an institution needs for its students' better performance and satisfaction (Bolton and Drew 1991). The services quality is mostly recognized by the cooperation of the administrative staff well as the faculty staff with the students. Majority of the students get de-motivated if they found that the staff is not compassionate and kind. According to Hasan et. al (2008) for quality assurance an institution must train its staff members in a way that it may create a sense of facilitation by means of coordination, cooperation, compassion and empathy (Jacoby and Chestnut 1978).

From the literature following hypotheses can be postulated.

H1: Increase in quality of services increases the students' satisfaction.

H2: Increase in quality of tangible services increase the students' satisfaction.

H3: Increase in quality of assured services increase the students' satisfaction.

H4: Increase in quality of reliable services increase the students' satisfaction.

H5: Increase in quality of responsive services increase the students' satisfaction.

H6: Increase in quality of empathy services increase the students' satisfaction.

\section{Methodology}

The present study aims at exploring the impact of service quality on students' satisfaction in higher education institutes of Punjab. These institutions include both public and private sector institutes. All these institutes are charted and regulated by the higher education commission of Pakistan (HEC). These educational institutions have similar functionality and code of conduct governed by the higher education commission of Pakistan. All these institutes have proper departmentalization and appropriate curriculum approved by the HEC. The similarity of working condition, educational courses and work climate thus constitutes the homogenous population and by selecting the sample of students of these institutes can be considered as the sample representing the entire population of the country. For the purpose of the study, a convenience sampling technique was used to record the responses of 240 students at a response rate of $96 \%$.

\subsection{Definition of Variables}




\section{Macrothink}

\subsubsection{Student Satisfaction}

It explains the satisfaction and contentment of students from the service quality of their institution. It is measured by the questionnaire developed by Atheeyaman (1997). All the responses are recorded on a five point likert type scale.

\subsubsection{Perceived service quality}

The perceived service quality is defined as the quality of a service that a student experience's after getting exposed of a certain service offered by his institute. It is comprised of five dimensions i.e.

\subsubsection{Tangible services}

The services which can be tangible like decoration of the furniture, cafeteria decoration, class layout etc.

\subsubsection{Reliability services}

The services of the administration, examination department to make the results reliable and correct address etc.

\subsubsection{Assurance services}

The services provided by the institution for which they assured the students about their academic.

\subsubsection{Empathy services}

The services of the institution which empathized the students are called the empathy services. Empathy reflects how much the university feels and cares the needs of students.

\subsubsection{Responsiveness}

It is defined as the immediate and efficient responsiveness of an institution's system. It explains how much the system is responsive towards the quality service providing.

Perceived Quality is measured by the questionnaire developed by Parasuraman et al. (1990) in which some items are taken from the questionnaire developed by LeBlanc and Nguyen (1997). All the responses are recorded on a five point likert type scale

\section{Analysis and Results}

The analysis of the data was done with the help of SPSS and AMOS. The overall reliability of the data i.e. Cronbach's Alpha was recorded at 0.89. The descriptive analysis shows the demographic characteristics of respondents with their institutes. There were no missing values in response. Overall males are 50 percent, while 50 percent are females. About 55 percent students are in graduation and 45 percent are in masters \& above. About 30.8 percent students are 15-20 years old, 53.8 percent are between 21-25 years old, 10 percent are between 25-30 years old and 5.4 percent are more than 30 years old and less than 36 years old. About 24.6 percent students are in $1^{\text {st }}$ semester of study in the universities, 11.7 percent are in $2^{\text {nd }}$ semester, 


\section{Macrothink}

Journal of Management Research

ISSN 1941-899X

2010, Vol. 2, No. 2: E10

25 percent are in $3^{\text {rd }}$ semester, 13.3 percent are in $4^{\text {th }}$ semester, 11.3 percent are in $5^{\text {th }}$ semester, 5.8 percent are in $6^{\text {th }}$ semester, 7.5 percent are in $7^{\text {th }}$ semester and 0.8 percent is in $8^{\text {th }}$ semester.

Table 1. Mean and Standard Deviation of Variables $(N=240)$

\begin{tabular}{|l|l|l|}
\hline Variables & Mean & SD \\
\hline Satisfaction & 3.22 & 1.10 \\
\hline Tangible service & 3.25 & .59 \\
\hline Assurance & 3.4 & .75 \\
\hline Reliability & 3.42 & .78 \\
\hline Empathy & 3.22 & .82 \\
\hline Total Service Quality & 3.32 & .60 \\
\hline
\end{tabular}

The mean values and standard deviation of the variables are given in the table 1 . The mean value of the reliability is the highest. $M=3.42$ which means that the students satisfactory level is based on how much they trust on the quality of the infrastructure, education, knowledge and abilities of faculty and other essentials of academic development like digital labs and quality of the stuff in library. They also seek the reliability and persistency of other services like cafeteria, play grounds class set up, and decoration. This reliability can only inspire them to be retained in their institution and develop them academically as well as professionally.

Table 2. Pearson's Correlation among Variables $\quad(N=240)$

\begin{tabular}{|l|l|l|l|l|l|}
\hline Variables & $\mathbf{1}$ & $\mathbf{2}$ & $\mathbf{3}$ & $\mathbf{4}$ & $\mathbf{5}$ \\
\hline Satisfaction & & & & & \\
\hline Tangible service & 0.453 & & & & \\
\hline Assurance & 0.363 & 0.587 & & & \\
\hline Reliability & 0.331 & 0.424 & 0.585 & & \\
\hline Empathy & 0.404 & 0.563 & 0.620 & 0.535 & \\
\hline Total Service Quality & 0.462 & 0.757 & 0.853 & 0.804 & 0.855 \\
\hline
\end{tabular}

**Correlation is significant at the level of 0.01. (Two- tailed).

The table 2 shows Pearson's Product Moment Coefficient Correlation. The highest correlation is found between empathy and total quality service i.e. $r=.855 p<0.01$. This shows that the compassion, coordination and kindness are the values that greatly add the quality to the service of an educational institution. Those institutions whose staff, faculty members and administration possess high level of human skills are assuring the quality education and are more satisfactory to the students. These polite, noble, caring, cooperative and motivating people working in an educational institution can raise the quality of educational service to its fullest extent. Like wise, the total service quality is also associated with the reliability of the services provided i.e. $r=0.853 p<0.01$. This shows that the reliability of the services will 


\section{Macrothink}

enhance the trust of the students on their institution as their institution is very much active in providing the quality education and learning environment for their academic development.

The analysis of the data is also done with AMOS, through structural equation modeling technique (SEM). The indicators were identified for the purpose of modeling. The indicators were identified on the basis of their factor loadings. These indicators are associated to their respective latent or unobserved variables to calculate the estimate. The values of SEM are given in the table 3.

Table 3. Structural Equation Modeling

\begin{tabular}{|c|c|c|c|c|c|c|c|c|}
\hline \multirow{2}{*}{$\begin{array}{l}\text { Values } \\
\text { Default Model }\end{array}$} & \multirow{2}{*}{$\begin{array}{r}\text { RMR } \\
.127\end{array}$} & \multirow{2}{*}{$\begin{array}{l}\text { GFI } \\
.825\end{array}$} & \multirow{2}{*}{$\begin{array}{c}\text { AGFI } \\
.778\end{array}$} & \multirow{2}{*}{$\begin{array}{l}\text { CFI } \\
.753\end{array}$} & \multicolumn{4}{|c|}{ NFI IFI RMSEA Chi square CMIN/DF P } \\
\hline & & & & & .663 .758 .084 & 536.4 & 2.68 & 0.00 \\
\hline
\end{tabular}

In table 3, the Goodness of Fit GFI $=.825$ Adjusted goodness of Fit AGFI=.778 comparative fit index $\mathrm{CFI}=.753$ and $\mathrm{IFI}=.758, \mathrm{NFI}=.663 \mathrm{RMR}=.127 \mathrm{RMESA}=.084$ and Chi square $=536.4$ with $\mathrm{p}=0.00$.

Since the GFI is affected by the sample size so in order to avoid this we can consider the CFI, RMESA and chi square which are not affected by the sample size. The over all analysis of the mode indicates that the model is a reasonable fit.

\section{Discussion \& Conclusions}

The present study aims at exploring the impact of service quality on students' satisfaction in higher education institutes of Punjab. The results show that the service quality greatly influences the students' satisfaction in multiple dimensions. The essence of students' satisfaction lies in the quality of teaching and learning environment of institution as students demand the well qualified, learned and experienced faculty for their academic and professional development. The students want to be teached by those teachers whose knowledge, expertise, liberality and reasonability up to the mark. The teaching methodologies and understanding with course and tasks with a friendly attitude of teaching are the key factors affecting the academic environment of an institution. The tangible facilities like class setup, digital labs and libraries, quality and reliability of the infrastructure and other assured facilities do contribute in creating the image of excellence.

We posited five hypotheses all of which are accepted. The structural equation modeling results have shown that the dimensions of service quality have a significant impact on the students' satisfactory level. The overall model is a reasonable fit showing that the tangibility, assurance, reliability and empathy have a strong and significant impact on the students' satisfaction from an institution. The results also showed that the cooperation, kindness of administrative staff and the responsiveness of the educational system play a vital role in retaining the students' interest as the administration should be responsible in providing all the essentials and necessities required progressive learning environment. The students seek the feelings of empathy, nobleness and kindness in their institute's administrative staff. Therefore the 
administration should be careful in training the employees in order to come up to the expectations of the students. In addition to the learning environment there are certain other essential facilities which are also important for the students i.e. the well managed cafeteria, parking facilities, play grounds and other arrangements of physical and mental health e.g. clubs, gymnasiums etc. Assuring all the facilities and quality of services with excellence and reliability, an institution can attract a lot of students by having its name in the leading educational institutions of learning.

\section{Research Implications}

The administrative executives and managers of the higher education institutes should pay attention in developing their educational institutes in the light of various dimensions of students' quality perception. They should comply with all the necessities, standards and requirements of quality education needed by their students. Especially the reliability of facilities being offered and most importantly the empathy of the administrative staff is a significant factor in quality perception. The nobleness of the staff i.e. their communication with students and their actions should be empathetic. Further the reliability of the infrastructure is also a very important preference of students of an institute. Thus in order to achieve maximum students' satisfaction, the facilitation with following dimensions of perceived quality should be the top priority of an institute.

\section{Limitations}

The size of sample is small. We think the research would have been more reliable if a greater size of sample will be used. Limitations also included Time and cost constraints, the difficulty we faced in gathering all the members of our focus group together at one venue, non serious attitude of people towards questionnaire filling. Geographical area is limited. It includes four cities. We select only ten universities out of all educational institutions for student satisfaction.

\section{Future Guidelines}

In future the other sources of students motivation and development should be specifically investigated i.e. the role of libraries in students learning, role of seminars and research conferences in grooming and learning development of students etc. The demographic impact of student satisfaction should also be investigated i.e. ethnicity, gender and religion do impact on the satisfaction from the perceived quality of the services delivered to the students. Further the data collection should be done with longitudinal data collection process in which qualitative data should be collected in order to gain the wide applicability of the research findings. 

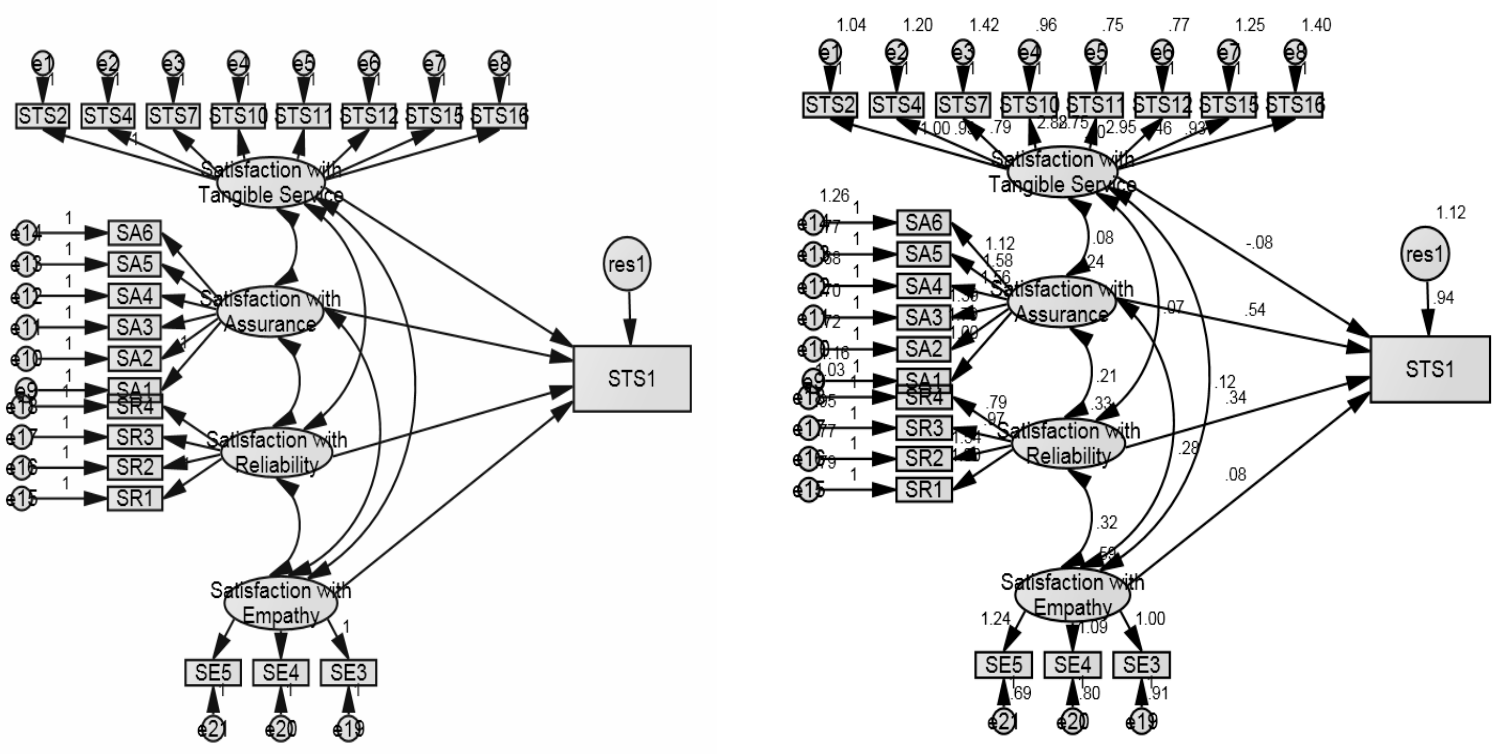

\section{References}

Alridge, S. \& Rowley, J. (2001). Conducting a withdrawal survey. Quality in Higher Education, 7(1), 55-63.

Atheeyaman, A. (1997). Linking student satisfaction and service quality perceptions: the case of university education. European Journal of Marketing, 31(7), 528-540.

Bolton, R.N. and Drew, J.H. (1991). A multistage model of customer's assessment of service quality and value. Journal of Consumer Research, 17(4), 365-84.

Dalton, H. \& Denson, N. (2009). Student evaluation: what predicts satisfaction? in The Student Experience. Proceedings of the 32nd HERDSA Annual Conference, Darwin, 100-110.

Dick, A.S. \& Basu, K. (1994). Customer Loyalty: Toward an Integrated Conceptual Framework. Journal of the Academy of Marketing Science, 22(2), 99-113.

Dyson, P., Farr, A. and Hollis, N.S. (1996). Understanding, measuring, and using brand equity. Journal of Advertising Research, 36(6), 9-21.

Edstrom, K. (2008). Doing course evaluations as if learning matters most. Higher Education Research and Development, 27, 95-106.

Elliot, K. \& Shin, D. (2002). Student satisfaction: An alternative approach to assessing this important concept. Journal of Higher Education Policy and Management, 24, 197-209. 
Galton, F. (2008). Bio-Medecine.org. data retrieved on 5 February 2008 from http://www.bio-medicine.org/biology-definition/Francis_Galton/.

Hasan, H. F. A., Ilias, A., Rahman, R. A. \& Razak, M. Z. A. (2008). Service Quality and Student Satisfaction: A Case Study at Private Higher Education Institutions. International Business Research, 1(3), 163-175.

Jacob, J. \& Chestnut, R. W. (1978). Brand Loyalty: Measurement and Management. New York: Wiley.

Keller, K.L. (1993). Conceptualizing, measuring and managing customer-based brand equity. Journal of Marketing, 57, 1-22.

Kotler, P. \& Clarke, R.N. (1987). Marketing for health care organizations. Englewood Cliffs, NJ: Prentice-Hall.

LeBlanc, G., \& Nguyen, N. (1997). Searching for excellence in business education: an exploratory study of customer impressions of service quality. International Journal of Educational Management, 11(2), 72-79.

Palacio, A. B., Meneses, G. D. \& Perez, P. J. P. (2002).The configuration of the university image and its relationship with the satisfaction of students. Journal of Educational Administration, 40(5), 486-505.

Parasuraman, A., Zeithaml, V. A. \& Berry, L. L. (1990). Five imperatives for improving service quality. Sloan Management Review, 29-38.

Rad, A. M. M. \& Yarmohammadian, M. H. (2006). A study of relationship between managers' leadership style and employees' job satisfaction. Leadership in Health Services, 19(2), 11-28.

Risch, R. A. \& Kleine, S .S. (2000). Customer Participation in Service Production and Delivery. In Handbook of Services Marketing and Management. Eds. Teresa A. Swartz and Dawn Iacobucci. Thousand Oaks: Sage, 111-125.

Rowley, J. E. (1996). Customer compatibility management: an alternative perspective on student-to-student support in higher education. International Journal of Educational Management, 10(4), 15-20.

Shevlin, M., Banyard, P., Davies, M. \& Griffiths, M. (2000). The validity of student evaluation of teaching in higher education: Love me, love my lectures? Assessment and Evaluation in Higher Education, 25, 397-405.

Spooren, P., Mortelmans, D. \& Denekens, J. (2007). Student evaluation of teaching quality in higher education: development of an instrument based on 10 Likert-scales. Assessment and Evaluation in Higher Education, 32, 667-679.

Sproule, R. (2000). Student evaluations of teaching: A methodological critique of conventional practices. Education Policy Analysis Archives, 8(50), 125-142. 


\section{Macrothink}

Journal of Management Research

ISSN 1941-899X 2010, Vol. 2, No. 2: E10

Soutar, G. \& McNeil, M. (1996). Measuring service quality in a tertiary institution. Journal of Educational Administration, 34(1), 72-82.

Wachtel, H. K. (1998). Student evaluation of college teaching effectiveness: A brief review. Assessment and Evaluation in Higher Education. 23(2), 191-212.

Zammuto, R. F., Keaveney, S. M. \& O’connor, E. J. (1996). Rethinking student services: assessing and improving service quality. Journal of Marketing in Higher Education, 7(1), 45-69.

Zeithaml, V.A. (1988). Consumer perceptions of price, quality, and value: a means-end model and synthesis of evidence. Journal of Marketing, 52, 2-22. 